\title{
Discovery of a Pleistocene mysticete whale, Georgia Bight (USA)
}

\author{
Ervan G. Garrison, Greg McFall, Alexander Cherkinsky, and Scott E. Noakes
}

\begin{abstract}
Subfossil evidence, including a nearly complete dentary ( $77 \%)$ (left mandible) and two badly eroded vertebrae, of a mysticete whale, were recovered, underwater, from an in situ context, in the Georgia Bight, $30 \mathrm{~km}$ offshore St. Catherine's Island, Georgia. The discovery of the mandible was initially made in 2006 but excavation was not completed until the summer of 2008 . Two badly preserved vertebrae were found lying nearby having eroded from the same outcrop as the dentary. The two vertebrae were dated but not analyzed in this report. Direct dating of the subfossils, with the Accelerator Mass Spectometry radiocarbon technique (AMS), using bioapatite, rather than collagen, suggests a common age range for the skeletal materials, 34,000 to $37,000 \mathrm{ka}$, but it's speculative to assign these remains to the same animal or, for that matter, the same taxon. The ages determined for the subfossils are in good agreement with the age of the geological deposit, a shell coquina, as previously determined by AMS dating of inclusions and by direct dating of the sediments using Optical Stimulated Luminescence (OSL) dating. Additionally, amino acid raceminization (AAR) ages were obtained for the coquina. Our comparative analysis supports a diagnosis of a dentary of a mysticete whale. Further comparison of preserved morphological characters with those for mysticete mandibles, support a further diagnosis as balaenopterid or eschrichtiid. Coupled with recent, Pleistocene aged discoveries, in Europe, in the North Sea basin, these remains could provide well-dated, new, North American evidence for the extirpated gray whale in the Atlantic basin of the Quaternary.
\end{abstract}

Ervan G. Garrison. Department of Geology, the University of Georgia (UGA), Athens, Georgia 30602, USA egarriso@uga.edu

Greg McFall. Gray's Reef National Marine Sanctuary, National Oceanic and Atmospheric Administration (NOAA), 10 Ocean Science Circle, Savannah, Georgia 34311, USA greg.mcfall@noaa.gov

Alexander Cherkinsky. Center for Applied Isotope Studies (CAIS), the University of Georgia, Athens, Georgia, 30602, USA acherkin@uga.edu

Scott E. Noakes. Center for Applied Isotope Studies (CAIS), the University of Georgia, Athens, Georgia, 30602, USA snoakes @uga.edu

Key Words: Whale; Mysticete; Pleistocene; Georgia Bight 


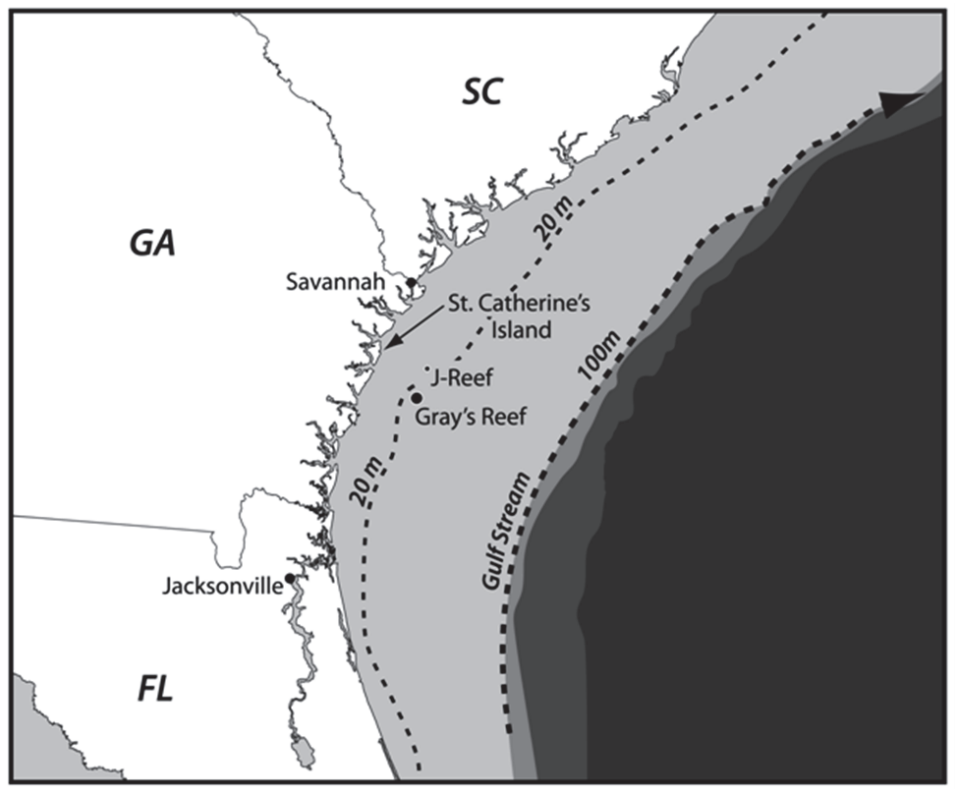

FIGURE 1. Location map for J Reef locality in the Georgia Bight, Atlantic Ocean.

\section{INTRODUCTION}

The discovery of late Pleistocene age subfossil remains of a mysticete whale(s), within an in situ, underwater location, in the Georgia Bight, provides direct for their presence in this portion of the Atlantic basin. If, as our upcoming analysis suggests, the remains are balaeonopterid or eschrichtiid, we can speculate, further, on these populations during the late glacial period.

If the dentary proves to be that of the extirpated Atlantic gray whale, Eschrichtius robustus, the find takes on additional meaning.

In this latter regard, the Atlantic gray whale, Eschrichtius robustus, was defined from subfossil evidence by John Gray in honor of Daniel Eschricht, cited by Cope (Lilljeborg, 1867). Cope (1865) originally considered the Pacific population to be another species but skeletal comparisons of that population's members to the Atlantic remains in the 1930s led to the acceptance of Gray's name, Eschrichtius robustus (Barnes and McLeod, 1984). The gray whale, while related to Balaeonoidea, occupies its own monotypic genus and family, Eschrichtiidae (Deméré et al., 2008). The fossil record for the gray whale is predominantly late Pleistocene-Holocene (Barnes and McLeod, 1984). At the family-genus level, two Pliocene discoveries have been assigned to Eschrichtiodidae Eschrichtiidae (Ichishima et al., 2006; Bisconti, 2008). Neither of these discoveries has been assigned to $E$. robustus.
The gray whale disappeared from the North Atlantic Ocean due, doubtless, to overhunting before 1700 (Mead and Mitchell, 1984; Lindquist, 2000). Subfossil evidence exists from localities in Europe and North America. These include seven localities in Europe and ten in North America. Post (2005) has reported recent, dated, subfossil Pleistocene aged, remains along the North Sea.

While mindful this specific find could be that of the Atlantic gray whale, we attempt to more securely diagnose its taxonomic position within the Mysticeti and, more specifically to either that of the balaeonopterids, in general, and Eschricthius, in particular. To this we use the preserved morphological characters of the the dentary in comparison to those well-defined for the mysticete whales, after Deméré et al. (2008).

\section{GEOLOGIC SETTING}

This paper presents a description of subfossil remains of one or more mysticete whales found during systematic geologic study of a paleontological locality composed of shell bed outcrops located along the $-20 \mathrm{~m}$ isobath in the Geogia Bight portion of the larger South Atlantic Bight (Figure 1) $\left(31^{\circ}\right.$ 36.016' N, $80^{\circ} 47.432^{\prime}$ W) (Noakes et al., 2009). The lithology is primarily an arenitic, medium-tofine weakly cemented sand that contains a rich invertebrate assemblage dominated by Placopecten magellanicus (sea scallop) (Garrison et al., 2008). The outcrops are an upper member of the Pleistocene-aged Satilla Formation (Huddleston, 


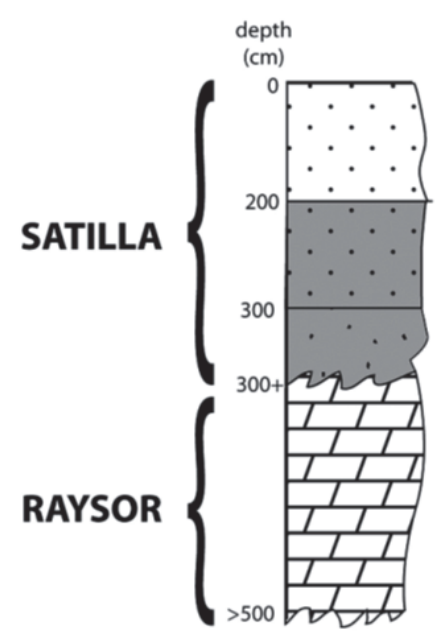

Geologic Section, this study, Satilla and Raysor Fms.
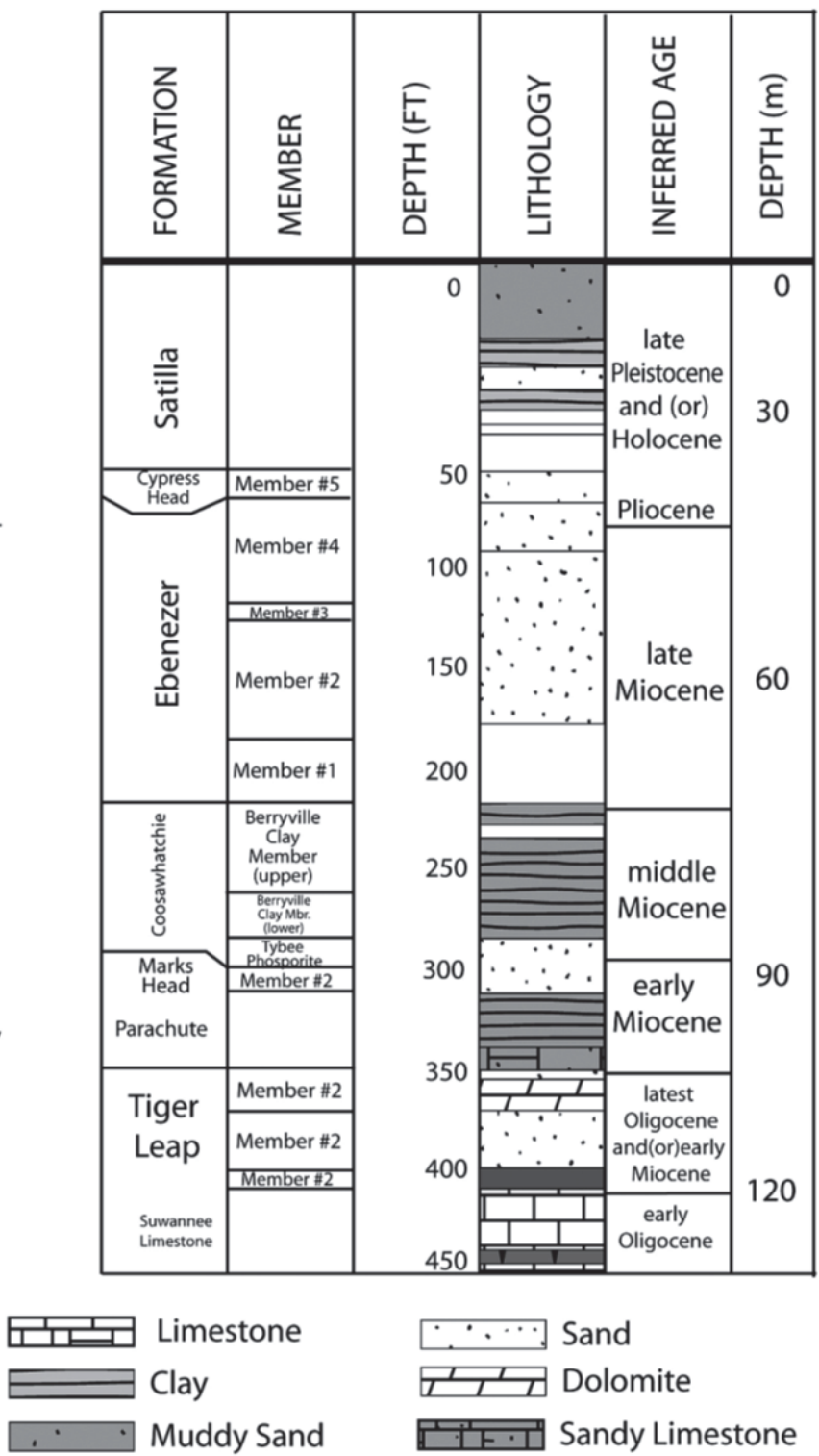

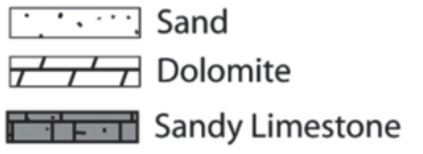

FIGURE 2. Generalized geologic section for coastal Georgia based on Weems and Edwards (2001). The inset corresponds to the upper portion of the general geologic section. The relative position for the mandible is marked.

1988) (Figure 2). Direct dating of the outcrop sediment (OSL) and of inclusions (shell, wood by AMS) give an age range of between 33,000 to 37,000 YBP for the deposits of Marine Isotope Stage (MIS) 3 (Cherkinsky et al., 2009; Garrison et al., 2008, table 3).

The outcrop was subaerial during a large portion of the last glacial period, from MIS 4 through MIS $2(71-24$ KYBP). During the fall of sea level from the Sangamon high stand (MIS 5e, ca. 125 KYBP), gray whales obviously frequented the South Atlantic Bight much as the Northern right whale (Eubalena glacialis) does today. Sometime, within MIS 3 (59-24 KYBP), while the area of today's outcrop was a shallow, nearshore locality, one or more whales stranded or floated ashore and were quickly buried in the fine sediments that are conformable with the overlying shell beds. These whale remains did not remain articulated, undergoing post-mortem taphonomic processes such as described by Liebeg et al., 2003: 172; Pyenson, 2010). All subfossil elements were all recovered within a $30 \mathrm{~m}$ radius of the in-situ mandible. Only this latter element was embedded. 
TABLE 1. Radiometric ages for sub-fossil elements using AMS-radiocarbon method.

\begin{tabular}{|c|c|c|c|c|c|c|}
\hline \multirow[b]{2}{*}{ UGA\# } & \multirow[b]{2}{*}{ Sample ID } & \multirow[b]{2}{*}{ Bone type } & \multicolumn{2}{|c|}{ Bioapatite } & \multicolumn{2}{|c|}{ Collagen-like organics } \\
\hline & & & $\delta^{13} \mathrm{C} \%$ & ${ }^{14} \mathrm{C}$ age, years $\mathrm{BP}$ & $\delta 13 c \%$ & ${ }^{14} \mathrm{C}$ age, years $\mathrm{BP}$ \\
\hline 4024 & GMNH-27370 & vertebra & -7.66 & $37,580 \pm 120$ & -20.96 & $10,630 \pm 40$ \\
\hline 4281 & GMNH-27372 & mandible & -6.62 & $36,570 \pm 300$ & -20.25 & $10,350 \pm 80$ \\
\hline 4215 & GMNH-27373 & vertebra & -6.67 & $34,520 \pm 160$ & -21.21 & $8,080 \pm 40$ \\
\hline
\end{tabular}

\section{SYSTEMATIC PALEONTOLOGY}

\author{
Class MAMMALIA Linneaus, 1758 \\ Order CETACEA Brisson, 1762 \\ Suborder MYSTICETI Gray, 1864 \\ Family ESCHRICHTIIDAE Ellerman and Morrison- \\ Scott, 1951 \\ Genus ESCHRICHTIUS Gray, 1864 \\ ESCHRICHTIUS ROBUSTUS.
}

Eschrichtius cf. E. robustus (Lilljeborg, 1867)

Type species: Balaenoptera robusta Lilljeborg, 1867, a subfossil skeleton from Gräsön, Roslagan, Upland, Sweden, in the University of Upsala; type by original designation by Gray, 1864 .

Alternatively, if the dentary is that of a balaenopterid whale, the systematic palaeontology can be:

\section{Class MAMMALIA Linneaus, 1758 Order CETACEA Brisson, 1762 \\ Suborder MYSTICETI Gray, 1864 \\ Family BALAEONOIDAE Gray, 1864 \\ Genus MEGAPTERA Gray, 1846 MEGAPTERA NOVAENGLIAE.}

Type species: Megaptera longimana, Gray, 1846.

In our comparative analysis and subsequent discussion we will focus primarily on these two genera because of the obvious similarity of the preserved features of the dentary.

\section{DATING}

All skeletal elements, mandible and associated vertebrae, were directly dated by the AMSradiocarbon method using the bioapatite fraction. In the case of all the finds the bone collagen fraction was used first to determine age (Table 1). Collagen in most fossil bones exists as a partially degraded complex even when the amino acid composition of the fossil bone collagen is identical to purified collagen (Tuross et al., 1980, 1988). The collagen fraction was almost completely destroyed, and the concentration of organic carbon was about $0.1 \%$ or lower. In all cases the bioapatite fractions have the older radiocarbon age in the range of 34-
$37.5 \mathrm{ka}$ than the organic, collagen-like, fractions, which were significantly rejuvenated with radiocarbon ages from 8.3-10 ka. The denser cortical bone is less exposed to attack by microorganisms and apparently still preserved some original collagen, which certainly has been contaminated by products of decomposition. These Pleistocene bones from an underwater context could not be dated by the organic fraction due to high microbiological activity, decomposition of original collagen and replacement with foreign organic matter, which is significantly younger than the bone itself. Because the dates obtained were so disparate relative to the age for the sediment outcrop/coquina - this is to say the bones were younger than the deposit - it was decided to date all elements using bioapatite, which is better preserved in bone that has undergone a long period of immersion in the marine environment. The range of AMS-RC ages (Table 1) for the bioapatite portion of the bones are consistent with the burial sediment ages of $32-44,000$ YBP obtained using AMS, OSL, U-Th and AAR ages for sediment and wood/shell inclusions (Garrison et al., 2008, table 3).

While the ages for these skeletal elements have a relatively tight time frame of $34-37,000$ YBP, the range of dating error does not permit a conclusion that all the skeletal elements represent one animal. Comparison of the carbon stable isotopes in Table 1 provide some evidence for the vertebra (UGA \# 4215) and the dentary being from the same animal (-6.67 versus $-6.62 \%$ ). The dates themselves militate against this conclusion as well as the results of taphonomic studies of marine mammals by other researchers (Liebig et al., 2003; Pyenson, 2010). Those studies of marine mammal death assemblages and attendant post-mortem processes argue for more disarticulated bones in shallow marine environments, in particular elements such as the mandible (Shäfer, 1972).

\section{DESCRIPTION}

The descriptions of the skeletal remains are as follows: 


\section{Dentary (UGA 4281; GMNH-27372)}

The specimen preserves many important characters of a mysticete mandible or dentary. Specifically, these characters include: (1) roughly eighty percent of the projected overall length for a complete dentary (chord length of $142 \mathrm{~cm}$, Table 2); (2) a preserved mandibular foramen (MF); (3) a partially preserved portion of the mandibular condyle (MC); (4) a small portion of the subcondylar process (SC); (5) the alveolar sinus (AS) (coronoid region to mid-length of the corpus) and the vestiges of a coronoid process (CP), dorsad (Figure $3)$.

Whereas these characters are certainly suggestive of a balaenid genus, as well as that of that of genus Eschrichtius, it should be noted: the dorsoventral curve of the dentary is not pronounced and the mylohyoidal cavity is missing together with that of the angular process. The coronoid process is damaged, and there is no evidence of the satellite process in the specimen.

The groove between the latter and the coronoid process - the coronoid satellite groove (g-c-s) - is partially preserved. The lack of these fully preserved characters makes it difficult, but, not in our view, impossible, to argue for the diagnosis of the mandible as that of a roqual genus such as Eschrichtius.

Viewed distally, (Figures 3, 4) the well-developed and complete mandibular foramen, together with the excurvate condylar region, proximal to the foramen, is seen. In cross-section, the dentary's distal aspect clearly shows an increase, proximal, to the lost condylar process. This portion of the specimen we refer to, after the convention of Field et al. (2011), as the "mandibular neck," in their discussion of Megaptera mandibles. Again, viewed distally, the clear outline of the base of the coronoid process, anterior of the mandibular foramen, appears. Posterior, medially, the incurvate nature of the mandibular neck is apparent, particularly on the medio-ventral surface.

The alveolar sinus begins anterior the coronoid process, dorsad, in the specimen. The observed width of the sinus is, perhaps, exaggerated by the eroded nature of this portion of the mandible.

Missing from this specimen, due also to erosion, is the groove between the coronoid and satellite processes (cf. Bisconti, 2008, p. 162). Also not observed is the mylohyoidal concavity along the medial surface of the dentary. These specific eschrichtiid features could be lacking in the speci-
TABLE 2. Eschrichtius robustus, holotype. Dentary measurements (in $\mathrm{mm}$ ).

\section{Specimen Number GMNH-27372}

\author{
Length (straight) $137 \mathrm{~cm}$ \\ Length (chord) $142 \mathrm{~cm}$ \\ Height at mandibular foramen $170 \mathrm{~mm}$ \\ Height at condyle (inferred) $190 \mathrm{~mm}$ (160 actual) \\ Height at coronoid process (inferred) 130 actual \\ (broken) \\ Minimum height between condyle and coronoid \\ process $170 \mathrm{~mm}$ \\ Circumference $100 \mathrm{~mm}$ behind proximal end $360 \mathrm{~mm}$ \\ Circumference $200 \mathrm{~mm}$ behind proximal end $470 \mathrm{~mm}$ \\ Circumference $300 \mathrm{~mm}$ behind proximal end $410 \mathrm{~mm}$ \\ Circumference $400 \mathrm{~mm}$ behind proximal end $460 \mathrm{~mm}$ \\ Circumference $500 \mathrm{~mm}$ behind proximal end $490 \mathrm{~mm}$ \\ Circumference $600 \mathrm{~mm}$ behind proximal end $492 \mathrm{~mm}$ \\ Circumference $700 \mathrm{~mm}$ behind proximal end $492 \mathrm{~mm}$ \\ Circumference $800 \mathrm{~mm}$ behind proximal end $492 \mathrm{~mm}$ \\ Circumference $900 \mathrm{~mm}$ behind proximal end $490 \mathrm{~mm}$ \\ Circumference $1000 \mathrm{~mm}$ behind proximal end $490 \mathrm{~mm}$ \\ Distance between condyle and coronoid process 300 \\ $\mathrm{mm}$ (inferred) \\ Distance between coronoid process and anterior end \\ 360 (inferred)
}

men, in part, because the anterior portion of the corpus is lost.

\section{COMPARATIVE ANALYSIS}

In general, the dentary is diagnostic in rorquals, notably the superfamily of Balaenopteroidea.

As such a specimen as described herein, albeit incomplete, is important in evaluating the paleontology of these whale clades. Recent DNA studies (Arnason and Best, 1991; Arnason and Gullberg, 1994, 1996), indicate the gray whale and Megaptera or more generally the Balaenoidae are more closely related than the other rorquals. Attempts to sequence DNA from the vertebrae and dentary failed, so our analysis, perforce, centers on the mandible's preserved characters.

The overall morphology of the dentary is clearly balaeopterid and similiar to that of Eschrichtius robustus with one significant exception: the lack of a well-defined mylohyoidal concavity, medially, along the mid-section of the ramus. Andrews (1914), however, reports little concavity on the 

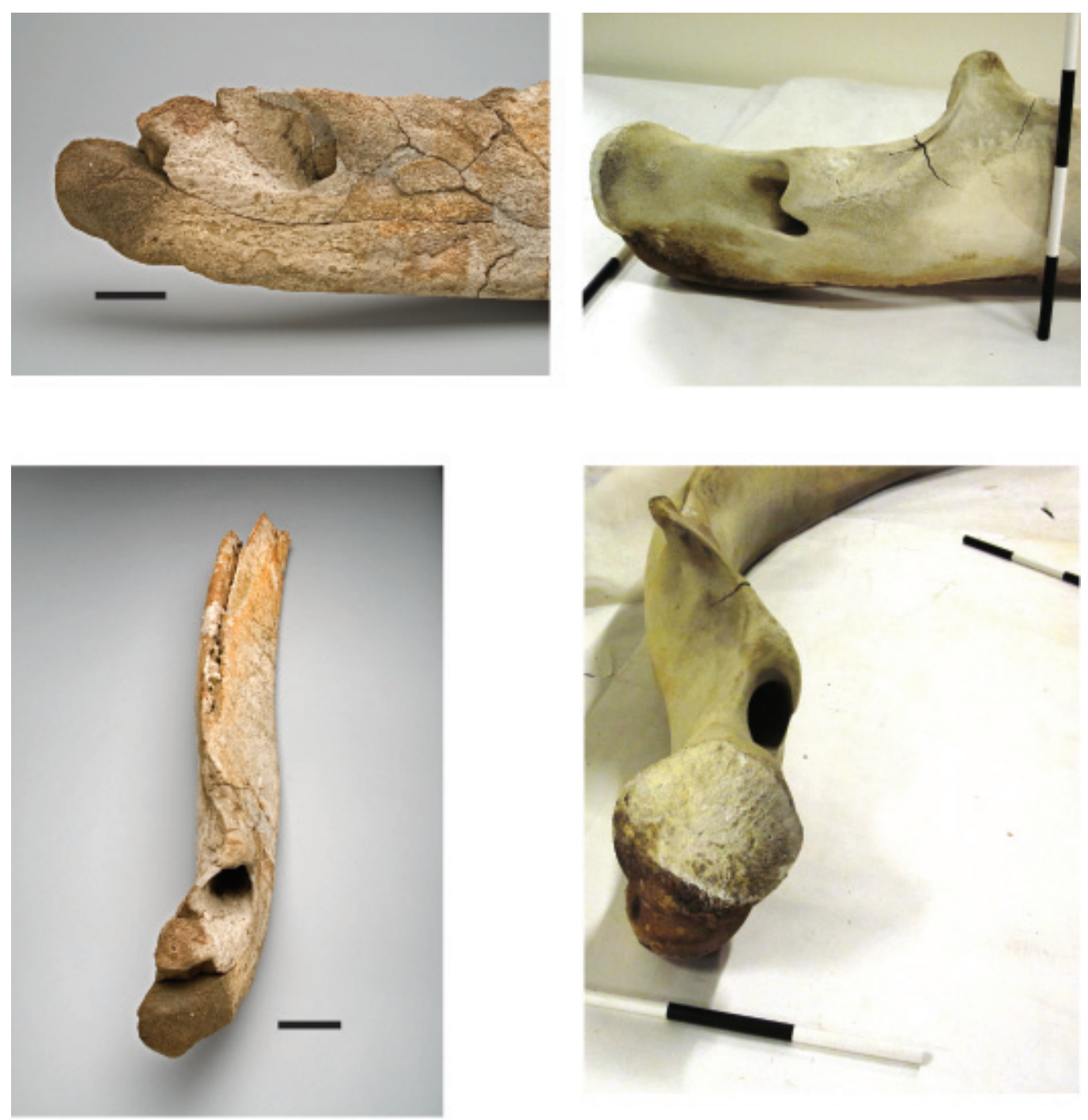

FIGURE 3. Comparative views - dentary : 3.1. Two views, medially, of the mandibular neck; 3.2. Two views, proximally, of the condylar region, Mysticete (left); Megaptera novaeangliae (right).

medial wall of the mandible, proximally, whereas Bisconti (2008), in his evaluation of a fossil eschrichtiid ( $E$. gastaldi), uses the mylohyoidal concavity as a distinguishing character. Other preserved characters of the dentary make the assignment of this specimen to the mysticetes, Balaenopterae and, ultimately, Eschrichtius robustus more parsimonious.

Following Deméré et al. (2008), the following morphological characters are diagnostic of mysticete whale mandibles:

1. Mandibular symphysis - sutured; not sutured: Not preserved in the specimen.

2. Mandibular neck (dorsal aspect) - straight neck vs. reflexed neck:
Preserved in the specimen, relatively straight.

3. Mandible, ventromedial groove - absent vs. present:

Not preserved in the specimen.

4. Mandible, curvature of ramus, in dorsal aspect - laterally concave; straight; laterally convex: Straight-to-laterally convex in the specimen,

5. Mandible, mandibular foramen size - large; small:

Large in the specimen.

6. Mandible, mandibular condyle orientation directed posteriorally; directed dorsally; directed posterior-laterally:

Partially preserved, directed posteriorally in the specimen. 

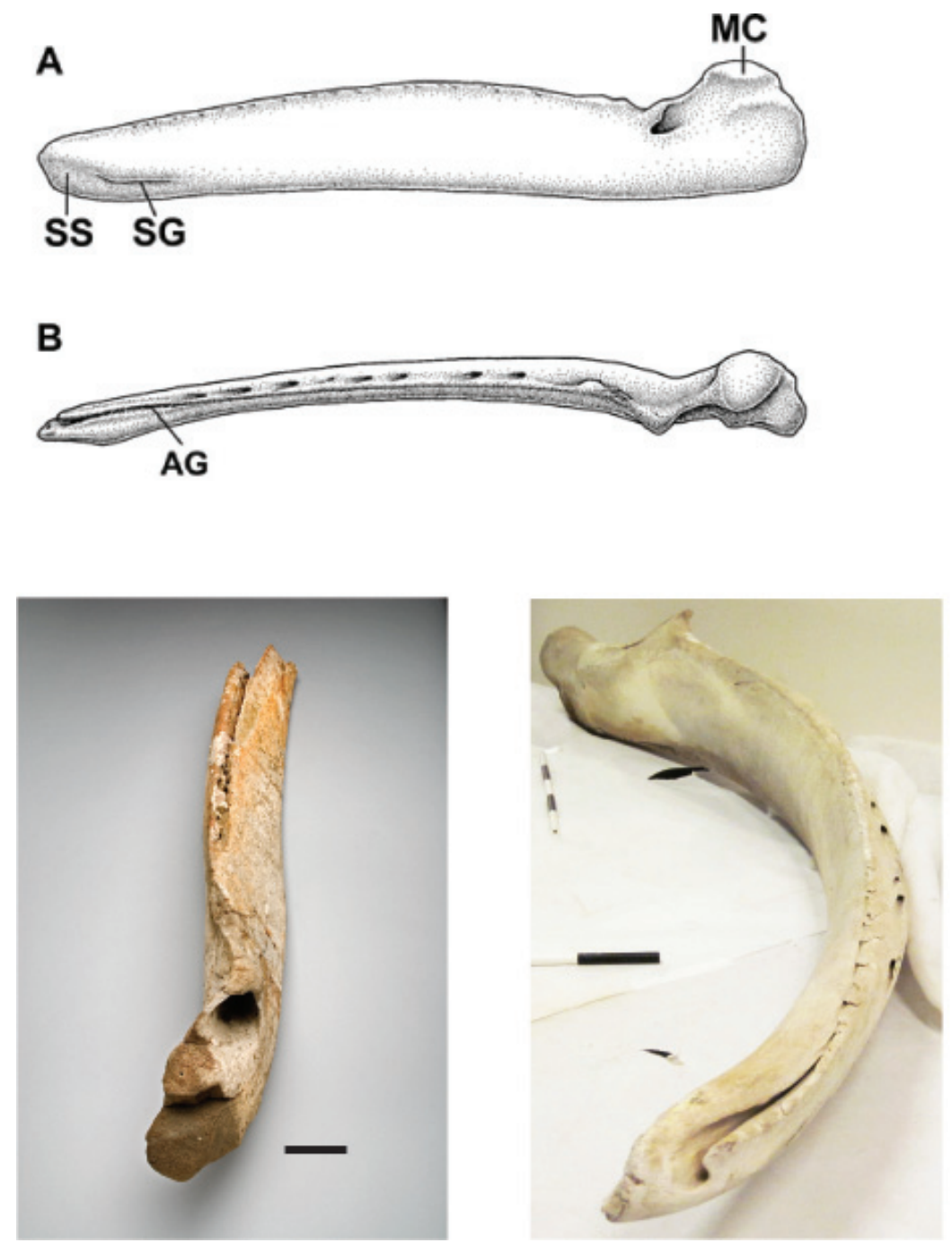

FIGURE 4. 4.1. Dentary of Eschrichtius robustus, from Johnston et al., 2010, figure 2, p. 189 (above); 4.2. Mysticete dentary (proximal view) compared to that of Megaptera novaeangliae (distal view).

7. Mandible, coronoid process - large and spatulate; finger-like and laterally deflected; developed as coronoid crest; developed and small knob and low crest; developed as rounded process with low crest:

Badly preserved in the specimen; suggestive of rounded process with low crest.

8. Mandible, position of coronoid process located relative close to the mandibular condyle; located relatively far from the mandibular condyle:

Coronoid process partially preserved in the specimen; relative position preserved close to the mandibular condyle.

9. Mandible, shape of the mandibular condyle transverally expanded and slightly cylindrical; bulbous and spherical; transverally com- pressed and ovoid:

Condylar region not well preserved in the specimen.

10. Mandible, orientation of the angle - posterior; posterior-ventrally:

Partially preserved in the specimen - posterior.

11. Mandible, proportional size of the mandibular angle relative to the mandibular condyle in the dorso-ventral plane - angle larger than the condyle; angle half the size of the condyle; angle severely reduced:

Condylar region not well preserved in the specimen.

12. Mandible, subangular furrow - absent; present:

Not preserved in the specimen. 
13. Mandible, relative position of anterior border of the mandibular foramen - Anterior to the coronoid process; in-line with the middle of the coronoid process; posterior to the coronoid process:

Preserved in the specimen; in line with the coronoid process.

Based on the comparison of the dentary's preserved characters, the specimen is securely placed within Mysticeti and more specifically the balaeonopterids to include genus Eschrichtius.

\section{DISCUSSION}

Cope (1871) observed that balaenopterids shared an elevated subtriangular and acuminate coronoid process in his description of "Megatera bellicosa" (M. novaeangliae). Bouetel (2005) states the gray whale shares this characteristic with the balaenids along with the more dorsally oriented mandibular condyle. Johnston et al. (2010) argue this homologous situation reflects a shared tempormandibular articulation that facilitates the engulfment-suction feeding mechanisms of the gray whale and the balaenopterids (see also Field et al., 2010), but, then suggest the gray whale's suction feeding (as compared to rorqual lunge feeding) leads to a reduction in the arching of the eschrichtiid dentary in comparison to the more broadly bowed dentaries of the balaeonopterids (Figure 4).

In their quantitative study of Megapterae mandibles, Field et al. (2010) state that rorqual mandibles consist of a bulbous posterior comprised of a dorsal condyle and ventral subcondylar process and a long, slightly curved corpus. Steeman (2007), in a phylogenetic analysis of fossil and living mysticetes, states that an expanded and arched mandible is not a synmorphy that supports the entire balaenoid-Eschrichtius clade, occurring to some extent in Eschrichtius.

Steeman further notes the anterior twisting of the mandible and the enlarged and rounded mandibular condyle is characteristic of Balaenoidea and not Eschrichtius (2007). Loss of the caudal and rostral portions of the specimen's dentary obviate a conclusive comparison of it to Megaptera or other of the Balaenopteridae.

The coronoid process was badly damaged and appreciatively lost but we argue it was either reduced or effectively rudimentary in this specimen (Figure 3). Likewise, the loss of the condylar and subcondylar terminae for this mandible does not allow for a full discussion except to note the observed portion - mandible neck and foramen - plus a cross-section breadth suggest a robust tempormandibular region consistent with that of Balaenopteridae. The preserved rostral portion of this mandible is not enough to confirm a twisting consistent with that characteristic of Eschrichtius robustus. The portion of the ramus that is preserved is flattened caudo-rostrally and moderately bowed as well as convex in cross-section (Figure 4), thereby supporting its assignment to Eschrichtius over that of genus Megaptera or other balaenopterids. The caudorostral cross-sectional area (Table 2) from 200 to $1000 \mathrm{~mm}$, of the ramus, is more suggestive of an eschrichtiid mandible than that of balaenopterids (Field et al., 2010).

\section{CONCLUSIONS}

Our description and analysis has centered on the preserved portions of the left dentary of a mysticete whale. The dentary, while badly preserved, is clearly that of a rorqual-type whale either a baleonopterid, such as Megaptera novaeangliae, or the closely related genus Eschrichtius, but not easily assignable to genus-species level. The mandible is more typical of Eschrichtius in terms of observed characters - reduced coronoid; flattened, moderately bowed (medially) ramus; and a laterally acuminate mandibular neck - than a balaeonopterid like Megaptera. All of the excavated remains are Pleistocene in age, 36-38 ka (Table 1), and contribute to the sparse data set for mysticete whales in the Atlantic Basin. The mandible's age of $36,570+/-300$ YBP makes it one of the oldest subfossil finds in the western Atlantic basin. If the find is that of a gray whale, the oldest present-day comparative example of a Pleistocene age gray whale comes from a recent find on the southern North Sea dating to 42,800 +/- 2700-4100 YBP (Post, 2005).

\section{ACKNOWLEDGMENTS}

The recovery of the subfossil was facilitated by personnel, vessel and equipment support from the National Oceanic and Atmospheric Administration (NOAA). R. Stein of the Michael C. Carlos Museum, Emory University, directed the reassembly and conservation of the find. N.D. Pyenson, Curator of Fossil Marine Mammals, Department of Paleobiology, National Museum of Natural History Smithsonian, identified the find as a gray whale and directed the casting of the subfossil. Drs. B. McLeod and T. Frasier, Department of Biology, St. Mary's University, Halifax, Nova Scotia, provided comments to the authors as well as conducting 
DNA studies of the find while at Trent University. The U.S. Army Corps of Engineers, Savannah District, provided permits to facilitate the excavation of the subfossil. Figures 3 and 4 images of the mandible were done by Montgomery Photography, Watkinsville, GA. All other artwork was done by W. Giminski, Athens, GA. All curation and transportation containers were constructed by Professor R.G. Brown, UGA's Lamar Dodd School of Art.

\section{REFERENCES}

Andrews, R.C. 1914. The California gray whale (Rhachianetes glaucus Cope): Its history, habits, external anatomy, osteology and relationship. Monographs of the Pacific Cetacea. Memoirs of the American Museum of Natural History, New Series:1:262-272.

Arnason, U. and Best, P.B. 1991. Phylogenetic relationships within the Mysticeti (whalebone whales) based upon studies of highly repetitive DNA in all extant species. Hereditas, 114(3):263-269.

Arnason, U. and Gullberg, A. 1994. Relationship of baleen whales established by cytochrome b sequence comparison. Nature, 367:726-728.

Arnason, U. and Gullberg, A. 1996. Cytochrome $b$ nucleotide sequences and identification of five primary lineages of etxtant cetaceans. Molecular Biological Evolution, 10:960-970.

Barnes, L.G. and McLeod, S.A. 1984. The fossil record and phyletic relationships of the gray whales, p. 3-32. In Jones, M.L., Swartz, S.L,.and Leatherhead, S. (eds.), The Gray Whale: Eschrichtius robustus. Academic Press, New York.

Bischonti, M. 2008. Morphology and phylogenetic relationships of a new eschrichtiid genus (Cetacea; Mysticeti) from the Early Pliocene of northern Italy, Zoological Journal of the Linnean Society, 153:161186.

Boutel, V. 2005. Phylogenetic implications of skull structure and feeding behavior in balaenopterids (Cetacea, Mysteceti). Journal of Mammalogy, 86:139-146.

Brisson, M.J. 1762. Le regnum animale in classes IX distributum, sive synopsis methodica sistens geenralem animalium distributiononem in classes $I X$, \& duarum primarum classium, quadrapedum scilicet \& cetaceorum, particularem dibvisionem in ordines, sectiones, genera \& species. T. Haak. Paris.

Cherkinsky, A., Noakes, S.E., Garrison, E.G., and McFall, G. 2009. Radiocarbon age of bone fractions from underwater collected gray whale bones, JY reef, offshore Georgia. Proceedings of the $20^{\text {th }}$ International Radiocarbon Conference, Hawaii, May 31June.

Cope, E.D. 1865. Notes on a species of whale occurring on the coasts of the United States. Proceedings of the Academy of Natural Science of Philadelphia, 17:168-169.
Cope, E.D. 1871. On Megaptera Bellicosa. Proceedings of the American Philosophical Society, 12(86):103108.

Deméré, T.A., McGowen, M.R., Berta, A., and Gates, J. 2008. Morphological and molecular evidence for a stepwise evolutionary transition from teeth to baleen in mysticete

Ellerman, J.R. and Morrison-Scott, J.C.S. 1951. Checklist of Palaearctic and Indian Mammals, 1758-1946. British Museum (Natural History), London.

Field, D.J., Campbell-Malone, R., Goldbogen, J.A., and Shadwick, R. 2010. Quantitative computed tomography of humpback whale (Megaptera novaeangliae) mandibles: Mechanical implications for rorqual lunge feeding. The Anatomical Record, 293:1240-1247.

Garrison, E.G., McFall, G., and Noakes, S.E. 2008. Shallow marine margin sediments, modern marine erosion and the fate of sequence boundaries, Georgia Bight (USA). Southeastern Geology, 45:127-142.

Gray, J.E. 1846. On British Cetacaea. Annals and Magazine of Natural History, [ser. 1], 17:83.

Gray, J.E. 1864. On the cetacean which have been observed in the seas surrounding the British Islands. Proceedings of the Zoological Society of London, 1864:82-85.

Huddleston, P.F. 1988. A revision of the lithostratigraphic units of the coastal plain of Georgia - Miocene through Holocene. Georgia Geological Survey Bulletin, 104.

Icshishima, H., Sato, E., Sagayama, T., and Kimura, M. 2006. The oldest record of Eschrichtidiiade (Cetacea: Mysticeti) from the Late Pliocene, Hokkaido, Japan, Journal of Paleontology, 80:367-379.

Johnston, C., Deméré, T.A., Berta, A., Yonas, J., and St. Leger, J. 2010. Observations on the musculoskeletal anatomy of the head of a neonate gray whale (Eschrichtius robustus). Marine Mammal Science, 26:186-194.

Liebeg, P.M., Taylor, T-S.A., and Flessa, K.W. 2003. Bones on the beach: marine mammal taphonomy on the Colorado delta, Mexico. Palaios,18:172.

Lilljeborg, W. 1867. On two subfossil whales discovered in Sweden. Nova Acta Regiae, Society of Science Uppsala, 3:1-48.

Linnaeus, C. 1758. Systema Naturae per regna tria naturae, secundum classis, ordines, genera, species cum characteribus, differentiis, synoymis, locis. Tenth ed. Vol. 1.Laurentii Salvii, Stockholm. 824 p.

Linquist, O. 2000. The North Atlantic gray whale (Eschrichtius robustus): An historical outline based on Icelandic, Danish-Icelandic, English and Swedish sources dating from ca $1000 \mathrm{AD}$ to 1792 . Occasional Papers I. Universities of St. Andrews and Sterling, Scotland.

Mead, J.G. and Mitchell, E.D. 1984. Atlantic Gray Whales, p. 33-53. In Jones, M.L., Swartz, S.L., and Leatherhead, S. (eds.), The Gray Whale: Eschrichtius robustus. Academic Press, New York. 
Noakes, S., McFall, G.A., and Garrison, E.G. 2009. Underwater paleontology: recovery of a prehistoric whale mandible offshore Georgia. In: Pollock, N.W. (ed.), Diving for Science 2009. Proceedings of the American Academy of Underwater Sciences 28th Symposium, Atlanta, GA.

Post, K. 2005. A Weichselian marine mammal assemblage from the southern North Sea. DEISEA, Annual of the Natural History Museum Rotterdam, 11:21-28.

Pyenson, N.A. 2010. Carcasses on the coastline: measuring the ecological fidelity of the cetacean stranding record in the eastern North America Pacific Ocean. Paleobiology, 36(3): 453-480.
Shäfer, W., 1972. Ecology and Paleoecology of Marine Environments. University of Chicago Press, Chicago.

Steeman, M.E. 2007. Cladistic analysis and a revised classification of fossil and recent mysticetes. Zoological Journal of the Linnean Society, 150: 875-894.

Tuross, N., Fogel, M.L., and Hare, P.E. 1988. Variability in the preservation of the isotopic composition of collagen for fossil bone, Geochimica et Cosmochimica Acta, 52:929-935.

Tuross, N., Eyre, D.R., Holtrop, M.E, Glimcher, M.J. and Hare P.E. 1980. Hoering, T.C. and King, K., (eds.), Biogeochemisiry of Amino Acids, John Wiley \& Sons. 